\title{
CPP-ACP complexe as an alternative to treatment of incisor molar hypomineralization: case report
}

\author{
Complexo CPP-ACP como alternativa ao tratamento da \\ hipomineralização molar incisivo: relato de caso
}

\author{
Micaela CARDOSO' ${ }^{1}$ iD 0000-0003-3063-5456 \\ Kelly Maria Silva MOREIRA ${ }^{1}$ iD 0000-0002-1137-3908 \\ Andréia Alves CARDOSO' ID 0000-0001-5271-2964 \\ Regina Maria Puppin RONTANI ${ }^{1}$ iD 0000-0002-1218-5159
}

\section{ABSTRACT}

The objective of this study was to report the clinical treatment of a child with Incisor Molar Hipomineralization. A 5-year-old Brazilian child, male gender, was diagnosed with Molar Incisor Hypomineralization, reporting high teeth sensitivity. After anamnesis and clinical examination, treatment was conducted with three weekly applications of fluoride varnish containing 5\% CPP-ACP complex. Also, it was advice to the patient for using a toothpaste containing fluoride and CPP-ACP (MI Paste Plus). After that, molars with great tooth structure loss were restored with resin modified glass ionomer cement. Prior to the first topical application of varnish with CPP-ACP and fluoride toothpaste containing CPP-ACP, a sensitivity test was conducted using thermal stimulus and facial pain scale. It was observed relative sensitivity decrease between sessions, reporting no sensitivity at the last session before the restoration. The treatment of Molar Incisor Hypomineralization teeth with CPP-ACP complex associated with fluoride varnish can be an alternative to reduce sensivity.

Indexing terms: Caseins. Dentition, permanent. Fluorides. Molar incisor. Tooth demineralization.

\section{RESUMO}

O objetivo desse estudo foi relatar o tratamento clínico de uma criança com Hipomineralização Molar Incisivo e, portanto, alto índice de sensibilidade dentária. Uma criança de cinco anos de idade, do gênero masculino, foi diagnosticada com Hipomineralização Molar Incisivo, relatando alta sensibilidade dentária. Após a anamnese e exame clínico, o tratamento iniciou-se com três aplicações de verniz fluoretado a 5\% com complexo de CPP-ACP, associado à um dentifrício fluoretado contendo CPP-ACP (MI Paste Plus), em intervalos semanais. Após as três sessões de aplicação de verniz, os molares com grande perda de estrutura dentária foram restaurados com cimento de ionômero de vidro modificado por resina (Vitremer). Previamente à primeira aplicação tópica do verniz fluoretado com CPP-ACP e utilização do dentifrício fluoretado contendo CPP-ACP foi realizado um teste de sensibilidade dentária usando estímulo térmico e escala facial de dor, repetindo-se a cada sessão. Verificou-se que a sensibilidade diminuiu entre as sessões, com ausência de sensibilidade na última sessão antes da restauração. O tratamento de dentes com Hipomineralização Molar Incisivo utilizando-se o complexo CPP-ACP associado à aplicação tópica de flúor pode ser uma alternativa para redução da sensibilidade dentária.

Termos de indexação: Caseínas. Dentição permanente. Fluoreto. Molar incisivo. Desmineralização do dente.

$\nabla \nabla \nabla v$

1 Universidade Estadual de Campinas, Faculdade de Odontologia, Departamento de Odontopediatria. Av. Limeira, 901, 13414-900, Piracicaba, SP, Brasil. Correspondência para / Correspondence to: RMP RONTANI. E-mail: <rmpuppin@gmail.com>.

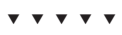

Cardoso M, Moreira KMS, Cardoso AA, Rontani RMP. CPP-ACP complexe as an alternative to treatment of incisor molar hypomineralization: case report. RGO, Rev Gaúch Odontol. 2019;67: e20190035. http://dx.doi.org/10.1590/1981-86372019000353657 


\section{INTRODUCTION}

Molar Incisor Hypomineralization (MIH) defines a situation comprising at least a hypomineralization of one or more first permanent molars and incisors, occured during amelogenisis, attributed to a systemic ethiology. This is clinically observed and can be a problematic condition for patients depending on the degree of severity [1]. In many cases, harmful pathogens in the first and second year of life are more common in children with $\mathrm{MIH}$. Asthma, pneumonia, respiratory infections, otitis media, antibiotics, breast milk dioxin, tonsillitis and tonsillectomy, and rash fevers in childhood may be directly related to $\mathrm{MIH}$ [2]. A study using animal models showed that amoxicillin affects the formation of dental enamel and it was largely affected when amoxicillin was used during the first year, with two times increase in risk [3]. However, the etiology of $\mathrm{MIH}$ remains uncertain [4].

Some congenital disorders such as amelogenesis imperfect (imperfect enamel development) and other acquired ones such as fluorosis may be confused with $\mathrm{MIH}$. In the literature, many different descriptions can be found for molars with white yellow or yellow brown demarcated opacities sometimes even in combination with enamel breakdown [5]. MIH differs from hypoplasia because it is a qualitative defect of the enamel that is clinically visualized as a demarcated opacity with clear and defined limits. The severity of $\mathrm{MIH}$ lesions can be characterized from demarcated opacities to structural loss that results in inlay or onlay restorations or even total crown destructions which can result in tooth extraction [6].

Poor and reduced mineral content, high porosity, low hardness, defective microstructure, increased carbonate content, poor bonding properties, and pulpal changes associated with $\mathrm{MIH}$ can induce extreme sensitivity, increased caries lesion risk, and physical breakdown during normal function [7]. Because of these aspects, mainly the molars presenting $\mathrm{MIH}$ are more susceptible to plaque buildup and consequent greater risk for caries, having greater need for dental treatment [7]. This is due to altered prismatic morphology of porous enamel. In addidion, the access of restorative material to enamel becomes difficult which leads to loss of restorative material and re-treatment or even to tooth extraction, as already described [8].

Treatment by remineralization therapy is recommended as soon as an MIH defect is identified in order to increase mineralization and eliminate sensitivity [9]. Topical fluoride application can be used to decrease sensitivity and demineralization [10]. Recent studies reported that dental materials containing CPP-ACP (casein phosphopeptideamorphous calcium phosphate) have been recommended, which shows that topical action causes remineralization and inhibition of sensitivity [1]. Although, given the absolute lack of in vivo studies and CPP-ACP supplementation trials as alternative treatment for teeth with $\mathrm{MIH}$, some authors suggest that protocols using dental materials containing CPP-ACP can help restore technical functional in treated $\mathrm{MIH}$ molars and aesthetics in untreated incisors [11].

Based on the above information on etiology, diagnosis, and treatment of $\mathrm{MIH}$, the aim of this study was to report a case of severe $\mathrm{MIH}$ associated with a high teeth sensitivity and establish its treatment based on the literature, using dental materials containing CPP-ACP/ Fluoride varnish associated with toothpaste containing CPP-ACP/Fluoride and teeth restorations.

\section{CASE REPORT}

A Brazilian male aged five years and five months was taken to the dental clinic at Piracicaba Dental School of the University of Campinas complaining by high teeth sensitivity and tooth breaking down, about which the patient had been complaining since the outbreak of the incisors and molars.

In the anamnesis, systemic alteration and allergy history to any product and medicine weren't report, according to information collected from the mother. Neither showed any reaction or allergy to milk protein. No stomatologic, periodontal, or joint commitment.

During clinical examination, the following changes were observed: cavitated carious lesions in maxillary primary molars (figure $1 \mathrm{~A}$ ) and mandibular primary molars (Figure 1B). In addition to the carious lesions, what stood out most was the presence of MIH observed in the maxillary permanent molars (figure 1A) and mandibular permanent molars (figure 1B) on both the right and left sides, and also in maxillary and mandibular incisors permanent (Figure 1C).

Molars and incisors treatment was conducted with topical application of fluoride varnish containing CPP-ACP complex in its composition (figures 1D and 1E) (MI Varnish, GC Corporation 76-1 HASUNUMACHO ITABASHI-KU, Tokyo, Japan). The manufacturer's instructions were 
followed performing one weekly application during three weeks. Along with this clinical treatment, the patient received fluoride toothpaste with CPP-ACP (MI Paste Plus, GC Corporation 76-1 HASUNUMACHO ITABASHI-KU, Tokyo, Japan) as an adjunct treatment. After three sessions, the molars with great loss of tooth structure were restored with resin modified glass ionomer cement (Vitremer 3M, Sumaré, São Paulo, Brazil) (figure 1F).

Prior to the first topical application of fluoride varnish with CPP-ACP and fluoride toothpaste containing CPP-ACP, a tooth sensitivity test was conducted using thermal stimulus and facial pain scale, a self-report measure of pain intensity developed for children. The scale make it possible to score the sensation of pain on the widely accepted 0 -to- 10 metric. The scale shows a close linear relationship with visual analog pain scales across the age range of 4-16 years [12-14]. Firstly, it was explained to the child how much something can hurt, showing the face chart. The smile face shows no pain. The faces show more and more pain pointing to each from left to right up to next one, until the last one, showing a very much pain. Then, it was asked to the child to point to the face that shows how much you hurt in each tooth with $\mathrm{MIH}$. The grade for each tooth and session was recorded in four appointments (table 1).
Pain measurement was performed at the beginning, during, and at the end of treatment, with no post treatment complaints of pain or sensitivity in teeth with $\mathrm{MIH}$. Pain level at the first appointment, before any treatment has been accomplished, was 5 (maximum level). Right after the first varnish application and toothpaste use, the pain level was decreased to 0 (no pain) for all teeth with $\mathrm{MIH}$. The patient and caregiver reported complete satisfaction with the treatment due to decreased sensitivity, improving chewing and dental oral hygiene quality.

Table 1. Tooth sensitivity test by visual analog pain scale.

\begin{tabular}{lcccc}
\hline Teeth & $1^{\text {st }}$ app & $2^{\text {nd }}$ app & $3^{\text {rd }}$ app & Final app/ before restoration \\
\hline 11 & 5 & 0 & 0 & 0 \\
12 & 5 & 0 & 0 & 0 \\
16 & 5 & 4 & 0 & 0 \\
21 & 5 & 0 & 0 & 0 \\
26 & 5 & 1 & 0 & 0 \\
36 & 5 & 0 & 0 & 0 \\
41 & 5 & 0 & 0 & 0 \\
42 & 5 & 0 & 0 & 0 \\
46 & 5 & 3 & 0 & 0 \\
\hline
\end{tabular}

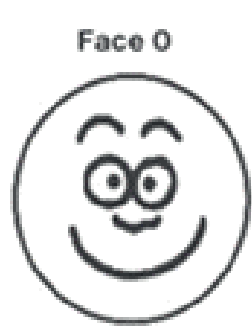

No Hurt

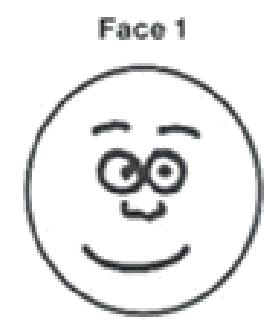

Hurts Little Bit

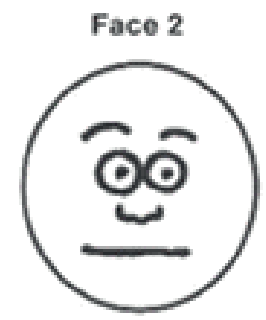

Hurts

Little More

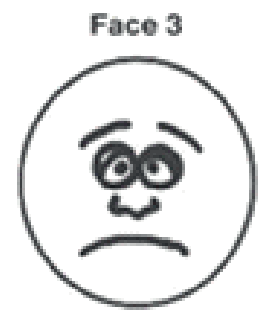

Hurts

Even More

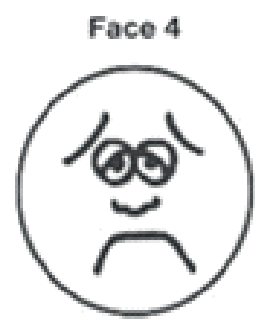

Hurts

Whole Lot

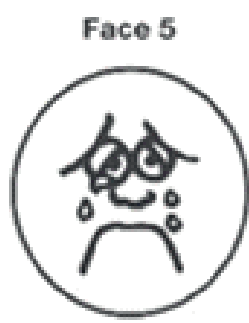

Hurts Worst

Explain to the individual that each face is for an individual who feels happy because he has no pain (hurt) or sad because he has some or a lot of pain. Face 0 is very happy because he does not hurt at all. Face 1 hurts just a little bit. Face 2 hurts a little more. Face 3 hurts even more. Face 4 hurts a whole lot. Face 5 hurts as much as you can imagine, although the individual does not have to be crying to feel this bad. Ask the individual to choose the face that best describes how he is feeling. This rating scale is recommended for individuals 3 years and older. Brief instructions: point to each face using the words to describe the pain intensity. Ask the individual to choose the face that best describes the pain and record the appropriate number.

Figure 1. Carious lesions in maxillary primary molars and hypomineralization in maxillary permanent molars (A). Carious lesions in mandibular primary molars and hypomineralization in mandibular permanent molars (B). Hypomineralization in maxillary and mandibular incisors permanent (C). Application of fluoride varnish containing CPP-ACP complex on permanent molars (D) and permanent incisors (E). Restoration with glass ionomer cement modified by resin in permanent molars after 3 weeks varnish CPP-ACP with fluoride application (F). 
In addition, restoration of cavitated carious lesions was carried out in maxillary primary molars with composites and extraction of the first mandibular primary molars due to pulp involvement and bone crypt of disruption. It was carried out early rehabilitation of missing teeth with removable space maintainer appliance with artificial teeth.

To finalize the molar hypermineralization, teeth was restored with resin modified glass ionomer cement (Vitremer, $3 \mathrm{M})$ according to the manufacturer's recommendations.

When the treatment was completed, the patient resumed the use of the toothpaste used pretreatment. Periodic controls of the patient were made guiding oral hygiene, dietary counseling, and evaluating pain intensity for 6 months, which last proved absent. Patients return periodically for control and prevention of carious lesions.

\section{DISCUSSION}

MIH is a dental defect that affects molars and incisors during enamel formation. Its prevalence ranges from $2.4 \%$ to $40.2 \%$ in different studies and it is likely that the cause is not related to a specific etiologic agent; however, these various factors act systematically affecting the development of tooth enamel during the prenatal, perinatal, or childhood period $[3,15]$.

Many factors such as asthma, pneumonia, upper respiratory tract infections, otitis media, antibiotics (amoxicillin), breast milk dioxins, and exanthematous fevers during childhood, among others, were involved in the formation of teeth with $\mathrm{MIH}$ [2]. In this case, during anamnesis, guardians were unaware of any report of these factors that could diagnose the cause of $\mathrm{MIH}$ in the cases reported.

Many clinical conditions can be associated with $\mathrm{MIH}$ such as masticatory problems, high pain level and aesthetic involvement. However, the effective treatment for $\mathrm{MIH}$ is a constant problem for dentists and some treatment approaches for $\mathrm{MIH}$ is broad from prevention (such as topical remineralizing agents) to invasive procedures such as restoration and even extraction recommendations include from application of remineralizing agents such as fluoride and CPP-ACP $[1,15,16]$.

The $\mathrm{MIH}$ approach treatment should consider the tooth signs and symptoms. Concerning no severe conditions, with no tooth structure loss, the MIH treatment should be focused on non invasive treatment in order to preserve the integrity of enamel; however, many professionals have no guidance as to effective treatment in this respect [4].

Topical application of fluoride varnish has been firstly used for enamel remineralization, and it can reduce of sensitivity and increase the resistance to demineralization by providing a reservoir of fluoride ions which redeposit on the enamel structure during remineralization.10 Authors suggest that there is considerable clinical benefit in topical application of fluoride on $\mathrm{MIH}$ to improve the hardness of softened surfaces [9]. Since the MIH tooth is poor mineral, the CPP present in the material can release a high concentration of calcium and phosphate, maintains a supersaturated mineral environment, reducing the demineralization and improving the enamel remineralization [17]. In addition, to the presence of sodium fluoride improve the CPP-ACP effect [15]. The action of this material used (CPP-ACP associated fluoride) explains the reduction of sensitivity in this case report according to Ozgül et al. [18].

By the other hand, MIH with lost of tooth structure should be primarily focused on stopping the pain. So, it can be treated both in relation to increase in mineral content and to reduced porosity of the lesions using gold standard techniques, such as desensitizing agents prior to restorative treatment [19].

In order to be successful in the treatment of $\mathrm{MIH}$ in this case it was performed topical application of CPPACP-containing varnish according to recommendations (once a week for 3 weeks) and concluded with fillings on the occlusal molars using glass ionomer cement modified by resin (Vitremer, 3M), with no enamel acid etching prior to restoration. Vitremer was used because of the advantages of a conventional glass-ionomer as well as of the high wear and fracture resistance necessary to be used for occlusal restorations, fractures and enamel or dentin malformations [20].

The child was pleased with the dental treatment that resulted in reduced tooth sensitivity for teeth that had hypomineralization, reporting improvement in feeding and also in invasive treatment such as fillings and extractions, which aimed to eliminate the sources of infection. The cooperation of the child was essential to the success and completion of treatment. 
Collaborators

M CARDOSO contributed to case planning, clinical care, data acquisition, analysis and critically revised the case report. KMS MOREIRA contributed to case planning, data acquisition, analysis and critically revised the case report. AA CARDOSO contributed to case planning, data acquisition, analysis and critically revised the case report. RMP RONTANI contributed to case planning, data acquisition, analysis and critically revised the case report.

\section{REFERENCES}

1. William V, Messer LB, Burrow MF. Molar incisor hypomineralization: review and recommendations for clinical management. Pediatr Dent. 2006;28(3):224-32.

2. Willmott NS, Bryan RA, Duggal MS. Molar-incisorhypomineralisation: a literature review. Eur Arch Paediatr Dent. 2008;9(4):172-9.

3. Lygidakis NA, Wong F, Jalevik B, Vierrou AM, Alaluusua S, Espelid I. Best clinical practice guidance for clinicians dealing with children presenting with molar-incisorhypomineralisation (MIH): an EAPD policy document. Eur Arch Paediatr Dent. 2010;11(2):75-81.

4. Mastroberardino S, Campus G, Strohmenger L, Villa A, Cagetti MG. An innovative approach to treat incisors hypomineralization (mih): combined use of casein phosphopeptide-amorphous calcium phosphate and hydrogen peroxide A case report. Case Rep Dent. 2012;2012:379593. doi: 10.1155/2012/379593

5. Koch $G$, Hallonsten AL, Ludvigsson N, Hansson BO, Holst A, Ullbro C. Epidemiologic study of idiopathic enamel hypomineralization in permanent teeth of Swedish children. Community Dent Oral Epidimiol. 1987;15(5):279-85. https:// doi.org/10.1111/j.1600-0528.1987.tb00538.x

6. Weerheijm KL, Duggal $M$, Mejàre I, Papagiannoulis L, Koch G, Martens LC, et al. Judgedement criteria for molar incisor hypomineralization $(\mathrm{MIH})$ in epidemiologic studies: a summary of the European meeting on $\mathrm{MIH}$ held in Athens. Eur J Paediatric Dent. 2003;4(3):110-3.

7. Leppaniemi A, Lukinmaa PL, Alaluusua S. Nonfluoride hypomineralizations in the permanent first molars and their impact on the treatment need. Caries Res. 2001;1:36-40. https://doi.org/10.1159/000047428

8. Espelid I, Haubek D, Birgitta J. Developmental defects of dental hard tissue and their treatment. In: Koch G, Poulsen S, editors. Pediatric dentistry: a clinical approach. 2nd ed. New Jersey: Wiley-Blackwell; 2009. p. 233-63.
9. Fayle SA. Molar incisor hypomineralization: Restorative management. Eur J Paediatr Dent. 2003;4(3):121-6.

10. Messer LB. Getting the fluoride balance right: Children in long-term fluori-dated communities. Synopses. 2005;30:7-10.

11. Baroni C, Marchionni S. MIH supplementation strategies: prospective clinical and laboratory trial. J Dent Res. 2011 Mar;90(3):371-6. https://doi.org/10.1177/002203451038 8036

12. McGrath PA, de Veber LL. The management of acute pain evoked by medical procedures in children with cancer. J Pain Symptom Manage. 1986;1(3):145-50. https://doi.org/10.10 16/S0885-3924(86)80063-X

13. McGrath PA. An assessment of children's pain: A review of behavioral, physiological and direct scaling techniques. Pain. 1987;31(2):147-71. https://doi.org/10.1016/0304-3959(87)9 0033-9

14. Lawrence J, Alcock D, McGrath P, Kay J, MacMurray SB, Dulberg $C$. The development of a tool to assess neonatal pain. Neonatal Netw. 1993 Sep;12(6):59-66.

15. Lygidakis NA. Treatment modalities in children with teeth affected by molar-incisor enamel hypomineralisation (MIH): a systematic review. Eur Arch Paediatr Dent. 2010;11(2):65-74.

16. Crombie FA, Manton DJ, Weerheijm KL, Kilpatrick NM. Molar incisor hypomineralization: a survey of members of the Australian and New Zealand Society of Paediatric Dentistry. Aust Dent J. 2008 Jun;53(2):160-6. https://doi.org/10.1111/j. 1834-7819.2008.00026.x

17. Vasconcelos AAMD, Cunha AGG, Borges BCD, Vitoriano JDO, Alves-Júnior C, Machado CT, et al. Enamel properties after tooth bleaching with hydrogen/carbamide peroxides in association with a CPP-ACP paste. Acta Odontol Scand. 2012 Jul;70(4):337-43. https://doi.org/10.3109/00016357.2011.6 54261

18. Ozgül BM, Saat S, Sönmez H, Oz FT. Clinical evaluation of desensitizing treatment for incisor teeth affected by molar-incisor hypomineralization. J Clin Pediatr Dent. 2013;38(2):101-5.

19. Crombie FA, Cochrane NJ, Manton DJ, Palamara JE, Reynolds EC. Mineralisation of developmentally hypomineralised human enamel in vitro. Caries Res. 2013;47(3):259-63. https:// doi.org/10.1159/000346134

20. Croll TP, Berg JH. Resin-modified glass-iomomer cement restoration of primary molars with proximating class II caries lesions. Compend Contin Educ Dent. 2007;28(7):372-7.

Received on: 29/8/2018

Final version resubmitted on: 23/11/2018

Approved on: 7/12/2018 